\title{
ANALISIS STABILITAS LERENG BATUAN DENGAN METODE PERKUATAN GROUND ANCHOR \& SOIL NAILING DI LABUAN BAJO, NTT
}

\author{
Lois Caroline Setiawan ${ }^{1}$, Gregorius Sandjaja Sentosa² dan Ali Iskandar ${ }^{3}$ \\ ${ }^{1}$ Program Studi Sarjana Teknik Sipil, Universitas Tarumanagara, Jl.Letjen S. Parman No.1 Jakarta \\ Email:lois30caroline@gmail.com \\ ${ }^{2}$ Program Studi Sarjana Teknik Sipil, Universitas Tarumanagara, Jl.Letjen S. Parman No.1 Jakarta \\ Email: Gregoriuss@ft.untar.ac.id \\ ${ }^{3}$ Program Studi Sarjana Teknik Sipil, Universitas Tarumanagara, Jl.Letjen S. Parman No.1 Jakarta \\ Email: ali.iskandar1999@gmail.com
}

\begin{abstract}
ABSTRAK
Stabilitas lereng yang akan ditinjau berada di daerah Labuan Bajo, Nusa Tenggara Timur. Bahaya longsor yang dapat terjadi di sekitar lereng sudah dapat teridentifikasi sejak awal perencanaan, namun hal tersebut diabaikan oleh pihak terkait sehingga penggalian tanah dilakukan secara langsung dengan sudut kemiringan lereng $70^{\circ}$ dengan tinggi lereng $>20 \mathrm{~m}$ tanpa adanya perkuatan. Sehingga pada tanggal 22 Agustus 2017 terjadi longsor yang menyebabkan munculnya retakan pada tepi jalan raya. Maka, diperlukan back analysis untuk memperoleh kestabilan lereng. Perkuatan yang digunakan adalah ground anchors dan soil nailing dengan sudut kemiringan pemasangan $30^{\circ}$ dan pemasangan dilakukan setiap jarak $2 \mathrm{~m}$. Back analysis ini dibantu dengan 2 program yaitu Plaxis 2D dan Geoslope Slope/W dengan kondisi undrained dan drained. Setelah dilakukan perkuatan, diperoleh nilai keamanan pada program Plaxis 2D adalah 2.7 untuk kondisi undrained dan 2.4 untuk kondisi drained. Selain itu, pada program Plaxis 2D akan menghasilkan nilai deformasi dan gaya tarik yang terjadi pada masing-masing perkuatan. Sedangkan pada program Slope/W hanya menghasilkan pola keruntuhan dan nilai keamanan. Nilai keamanan yang diperoleh untuk kondisi undrained berkisar 2.5 dan kondisi drained berkisar 2.2-2.4.
\end{abstract}

Kata kunci: stabilitas lereng, nilai keamanan, soil nailing, ground anchor, Plaxis 2D, Slope/W

\section{PENDAHULUAN}

Lereng terdiri dari lereng buatan dan lereng alami yang terbentuk dari kontur bumi. Maka, dapat diartikan lereng adalah permukaan tanah yang memiliki perbedaan ketinggian yang dibentuk oleh manusia maupun alamiah dengan sudut kemiringan tertentu yang diukur dari arah horizontal. Lereng dapat menjadi tidak stabil sehingga dapat menyebabkan sebuah kegagalan (longsor) yang diakibatkan oleh kuat geser tanah yang lebih kecil dibandingankan dengan tegangan geser yang terjadi pada lereng.

Dalam menangani hal tersebut, diperlukan analisis stabilitas lereng dengan parameter tanah yang telah disediakan. Dimana dalam menganalisis stabilitas lereng nilai faktor keamanan harus perlu diperhitungkan. Karena dengan semakin tingginya nilai faktor keamanan, potensi lereng mengalami kegagalan akan kecil. Kemudian, setelah melakukan analisis maka diperlukan penentuan konstruksi perkuatan lereng yang efisien. Analisis stabilitas lereng dapat dibantu dengan 2 software yaitu Plaxis 2D dan Geoslope. Untuk kasus yang terjadi di Labuan Bajo desain awal yang digunakan adalah soil nailing. Namun, karena masalah waktu pekerjaan pihak-pihak yang terkait mengabaikan langkah pelaksanaan yang harus diikuti sehingga langsung dilakukan penggalian sehingga menyebabkan kelongsoran yang akan diperkuat dengan ground anchor dan soil nailing. Tujuan penelitian ini adalah menganalisis perbedaan safety factor, deformasi, dan gaya tarik yang terjadi pada lereng setelah diberikan perkuatan, mengetahui pola keruntuhan yang terbentuk, menganalisis perbedaan kondisi undrained dan drained pada software Plaxis 2D dan Geoslope.

\section{Faktor keamanan stabilitas lereng}

Menurut SNI 8460:2017 “Persyaratan Perancangan Geoteknik”, nilai faktor keamanan untuk lereng batuan yang stabil dapat dilihat pada tabel 1. Selain itu, Bowles (1984:597) menyatakan nilai keamanan berdasarkan studi keruntuhan lereng pada tabel 2. 
Tabel 1 Rekomendasi Nilai Faktor Keamanan Untuk Lereng Batuan

\begin{tabular}{|c|c|}
\hline $\begin{array}{c}\text { Kondisi Lereng } \\
\text { Batuan }\end{array}$ & $\begin{array}{c}\text { Rekomendasi } \\
\text { nilai faktor } \\
\text { keamanan }\end{array}$ \\
\hline Kondisi Permanen & 1.5 \\
\hline Kondisi Sementara & 1.3 \\
\hline
\end{tabular}

Tabel 2 Faktor Keamanan Berdasarkan Studi Keruntuhan Lereng

\begin{tabular}{|c|c|}
\hline Faktor Keamanan & Kondisi \\
\hline $\mathrm{F}<1.07$ & Keruntuhan dapat terjadi \\
\hline $1.07<\mathrm{F} \leq 1.25$ & Keruntuhan mungkin terjadi \\
\hline $\mathrm{F}>1.25$ & Keruntuhan jarang terjadi \\
\hline
\end{tabular}

\section{Ground anchor (angkur tanah) dan soil nailing}

Ground anchors merupakan salah satu cara perbaikan konstruksi tanah yang berfungsi untuk menyalurkan gaya tarik yang bekerja pada angkur ke lapisan tanah atau batuan pendukung. Gaya tarik tersebut berfungsi untuk memberikan keseimbangan antara angkur, struktur yang akan diangkur, dan pada tanah yang ada disekitarnya. Soil nailing adalah suatu perkuatan lereng yang bersifat pasif dengan menggunakan batang baja (nail bar) yang berfungsi untuk memindahkan beban ke tanah sekitar soil nailing. Efek yang diberikan adalah meningkatkan gaya normal dan perlawanan tahanan geser tanah selama terjadi potensial gelincir dan mengurangi gaya dorong pada bidang gelincir.

\section{Plaxis 2D}

Program plaxis merupakan program yang didasarkan oleh metode elemen hingga (finite element) yang menyimulasikan perilaku tanah untuk mendapatkan nilai deformasi dan stabilitas dari suatu struktur geoteknik yang dibangun. Analisis perhitungan yang dilakukan pada kondisi plane-strain dan axis-symetric. Model geometri ini terdiri dari points, lines dan clusters.

\section{Geoslope}

Geoslope merupakan suatu program yang didasarkan pada metode prinsip kesetimbangan gaya (limit equlibrium). Fungsi dari program ini adalah untuk menghitung faktor keamanan berdasarkan kondisi pelapisan material. Program ini didasarkan pada metode limit equilibrum, analisis kelongsoran yang akan dihitung dengan mengasumsikan bidang kelongsoran menjadi circular atau non circular yang dibagi menjadi beberapa bagian (slices).

\section{METODOLOGI PENELITIAN}

\section{Metode pengumpulan dan analisis data}

Data yang digunakan diperoleh dari 7 data bore log lama dan 4 data bore log baru. Data tersebut digunakan untuk korelasi parameter tanah yang akan di input ke dalam Plaxis $2 D$ dan Geoslope. Parameter tanah dibedakan menjadi kondisi undrained dan drained.

\section{Pemodelan lereng dan perkuatan lereng}

Pemodelan lereng menggunakan Plaxis $2 D$ dan Geoslope, lereng tersebut akan digali secara langsung sampai kedalaman 28.5 yang selanjutnya dicek nilai keamanannya. Jika nilai yang diperoleh $\geq 1.5$, diperlukan reduksi parameter hingga mendekati nilai 1.07 untuk mengkondisikan keadaan sesuai lapangan yang mengalami longsor. Setelah didapat, gunakan paramater tersebut dan lakukan pemodelan perkuatan dengan ground anchor dan soil nailing sehinggga diperoleh nilai $\mathrm{SF} \geq 1.5$. 


\section{HASIL PEMBAHASAN}

Back analysis yang akan dilakukan untuk menganalisis kelongsoran yang terjadi di Labuan Bajo akan dibantu dengan 2 program yaitu Plaxis $2 D$ dan Geoslope. Lereng akan dikondisikan menjadi undrained dan drained. Pada program Geoslope perhitungan analisis akan dilakukan dengan menggunakan metode grid and radius.

\section{Klasifikasi tanah pada lereng longsor}

Berdasarkan hasil data bore log, diperoleh klasifikasi tanah yang terkandung terdiri dari 3 lapisan yaitu lapis 1 dengan tipe Clay (Stiff-V.Stiff), lapis 2 dengan tipe Clay, (Hard), dan lapis 3 dengan tipe Sand (V.Dense) yang dapat dilihat pada gambar 1 .

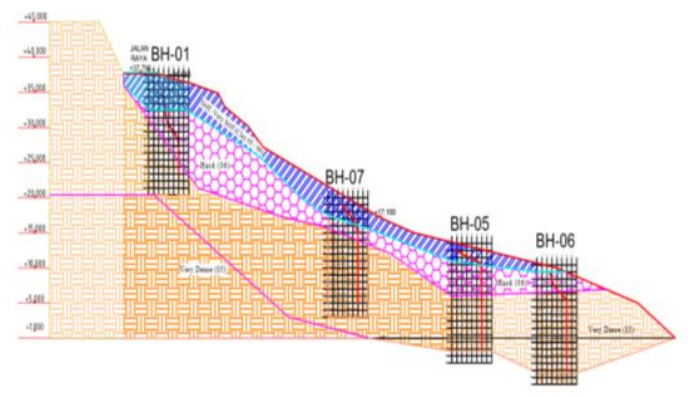

Gambar 1 Klasifikasi Tanah

\section{Hasil analisis lereng kondisi undrained pada plaxis $2 D$}

Pada kondisi undrained dilakukan analisis pada tahapan penggalian secara langsung sampai kedalaman $28.5 \mathrm{~m}$, kemudian dilakukan reduksi parameter karena nilai SF yang tidak mendekati 1.07, dilakukan penanganan sementara dengan counterweight pada kaki lereng, dan pada tahap terakhir pemodelan perkuatan lereng untuk keadaan statis dan dinamis (gempa). Nilai keamanan yang dihasilkan pada masing-masing tahapan dapat dilihat pada gambar 2.

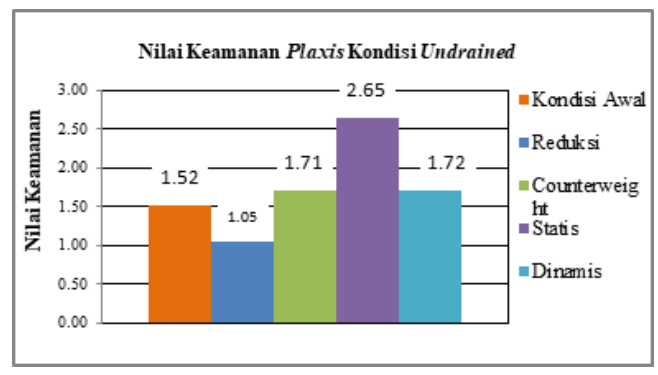

Gambar 2 Rangkuman Nilai Keamanan Kondisi Undrained Plaxis 2D

Berdasarkan gambar 2, nilai keamanan setelah dilakukan perkuatan meningkat sehingga lereng dikatakan telah stabil dan memenuhi syarat keamanan untuk statis $\mathrm{SF} \geq 1.5$ dan dinamis $\mathrm{SF} \geq 1.3$. Pola kelongsoran yang terjadi dapat dilihat pada gambar 3,4,5, dan 5 .

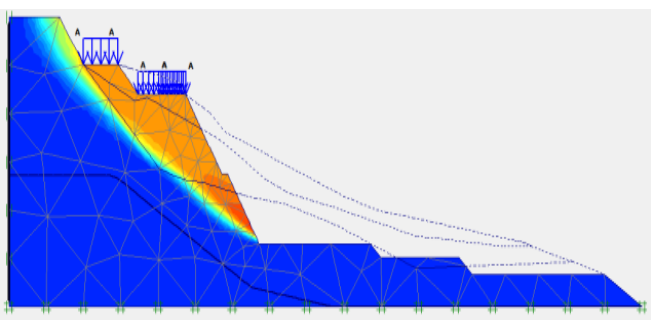

Gambar 3 Pola Kelongsoran Undrained Untuk Kondisi Awal

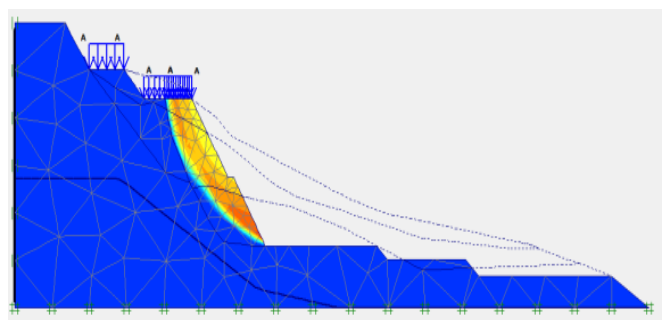

Gambar 4 Pola Kelongsoran Undrained Untuk Reduksi Parameter 


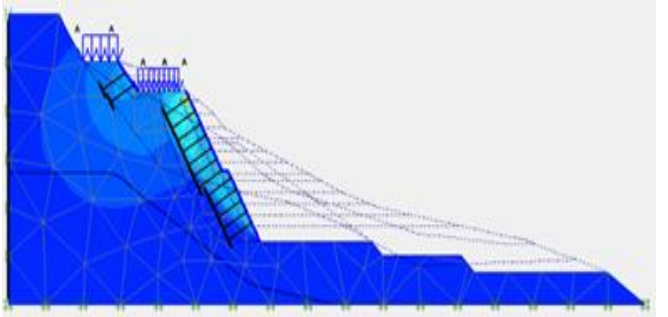

Gambar 5 Pola Kelongsoran Undrained Perkuatan Lereng Keadaan Statis Plaxis 2D

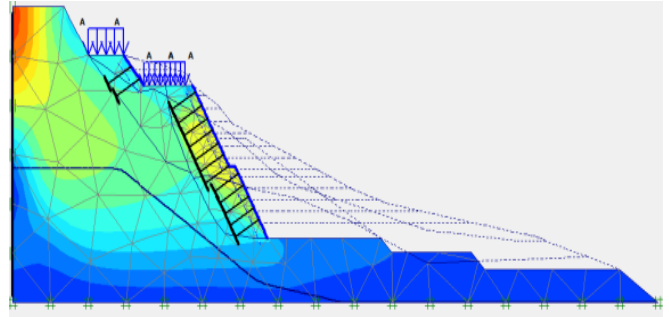

Gambar 6 Pola Kelongsoran Undrained Perkuatan Lereng Keadaan Dinamis Plaxis 2D

\section{Hasil analisis lereng kondisi drained pada plaxis $2 D$}

Pada kondisi drained tidak dilakukan reduksi karena nilai SF saat penggalian langsung sudah mendekati nilai 1.07. Gambar 7 adalah nilai keamanan pada tahapan penggalian langsung sampai dilakukan perkuatan. Nilai keamanan yang dihasilkan untuk keadaan statis dan dinamis stabil. Pola keruntuhan yang dihasilkan pada masing-masing tahapan dapat dilihat pada gambar 8,9, dan 10 .

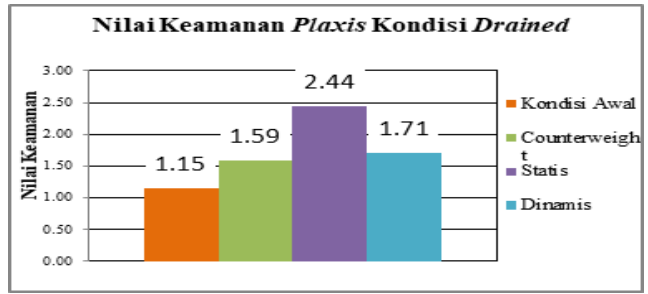

Gambar 7 Rangkuman Nilai Keamanan Drained Plaxis 2D

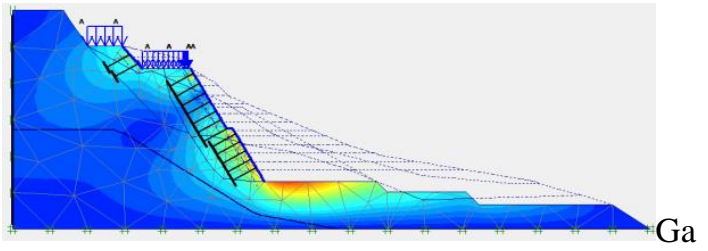

mbar 9 Pola Kelongsoran Drained Keadaan Statis Plaxis 2D

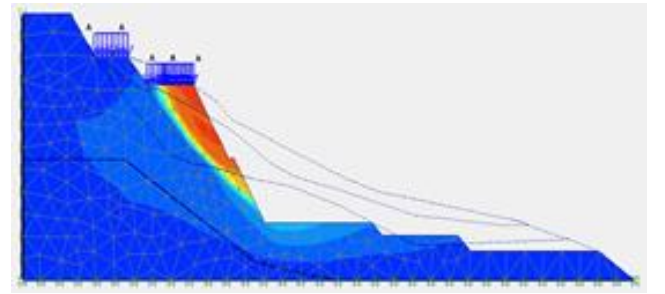

Gambar 8 Pola Kelongsoran Drained Kondisi Awal

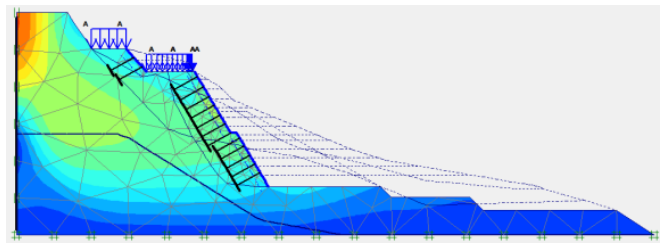

Gambar 10 Pola kelongsoran Drained Keadaan Dinamis Plaxis $2 D$

\section{Hasil analisis lereng kondisi undrained pada geoslope dengan metode grid and radius}

Dalam program Geoslope hasil yang diperoleh adalah nilai keamanan pada gambar 11 dan bidang longsor yang berbentuk circular. Perkuatan pada program ini dimodelkan sebagai point loads. Besaran point loads untuk soil nailing sebesar $27.579 \mathrm{kN}$ untuk keadaan statis dan keadaan dinamis sebesar $270.995 \mathrm{kN}$. Sedangkan, untuk ground anchor berasal dari gaya prestress $642.95 \mathrm{kN}$.

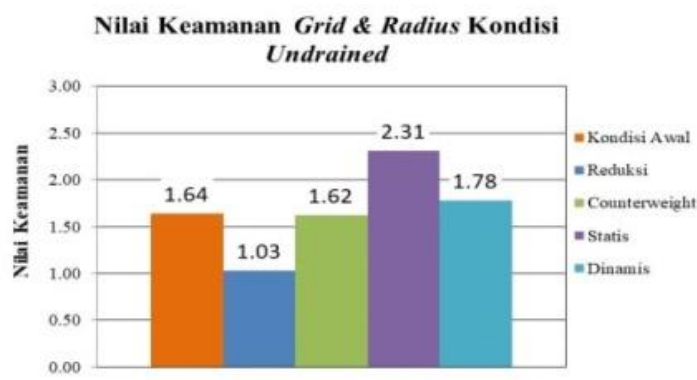

Gambar 11 Rangkuman Nilai Undrained Pada Geoslope Metode Grid and Radius 
Berdarakan gambar 11, nilai keamanan dari program Geoslope pada saat perkuatan digunakan lereng dinyatakan stabil. Pola kelongsoran dapat dilihat pada gambar 12,13,14, dan 15.

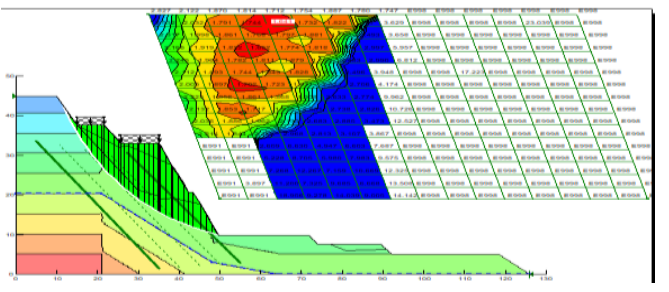

Gambar 12 Pola Kelongsoran Undrained Kondisi Awal Metode Grid and Radius

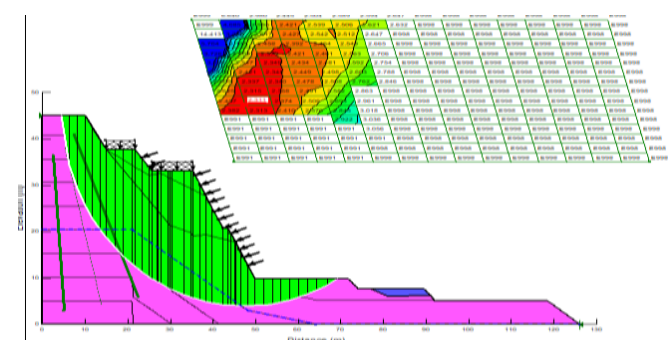

Gambar 14 Pola Kelongsoran Undrained Keadaan Statis Metode Grid and Radius

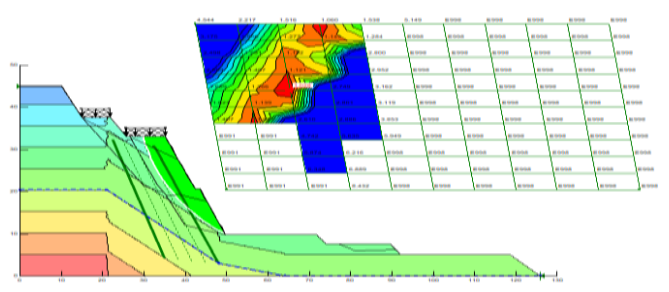

Gambar 13 Pola Kelongsoran Undrained Untuk Reduksi Parameter Metode Grid and Radius

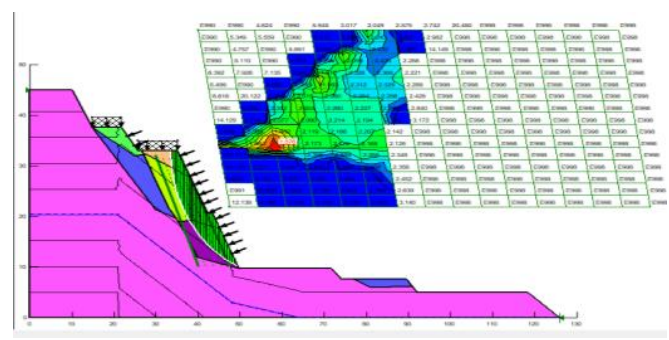

Gambar 15 Pola Kelongsoran Undrained Keadaan Dinamis Metode Grid and Radius

\section{Hasil analisis lereng kondisi drained pada pada geoslope dengan metode grid and radius}

Tahapan dalam menganalisis kondisi drained dengan program Geoslope sama seperti pada Plaxis 2D yang tidak memerlukan reduksi parameter. Nilai keamanan yang dihasilkan pada kondisi drained dapat dilihat pada gambar 16 yang menyatakan bahwa lereng sudah dalam keadaan stabil setelah adanya perkuatan. Pada pemasangan perkuatan dimana untuk keadaan statis pada nailing besaran point loads yang diberikan adalah $10.518 \mathrm{kN}$ dan keadaan dinamis adalah 264.0849 kN. Sedangkan, untuk ground anchor diberikan beban sebesar $642.95 \mathrm{kN}$.

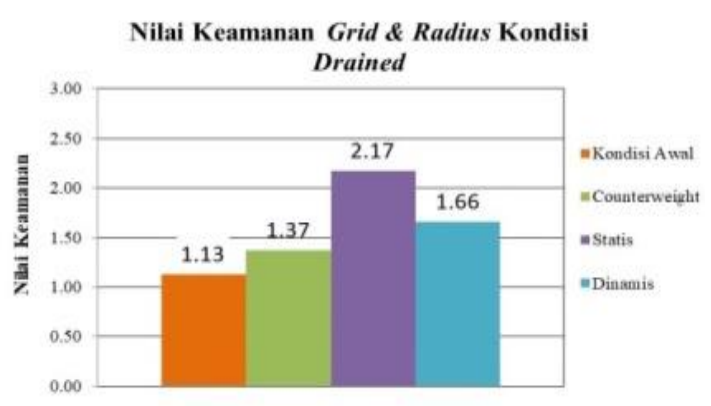

Gambar 16 Rangkuman Nilai Keamanan Drained Metode Grid and Radius

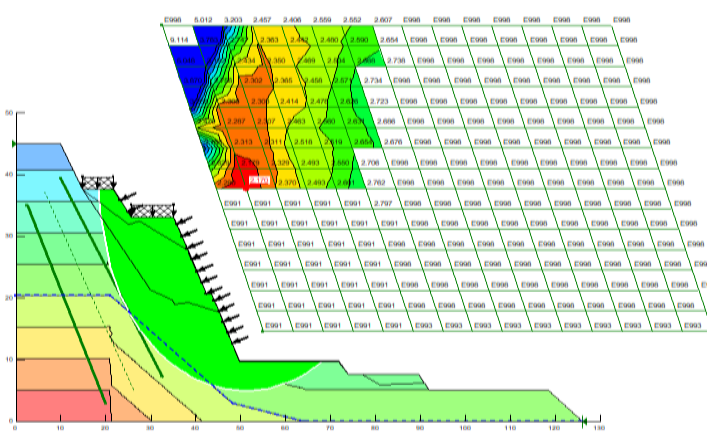

Gambar 18 Pola Kelongsoran Drained Keadaan Statis Metode Grid and Radius

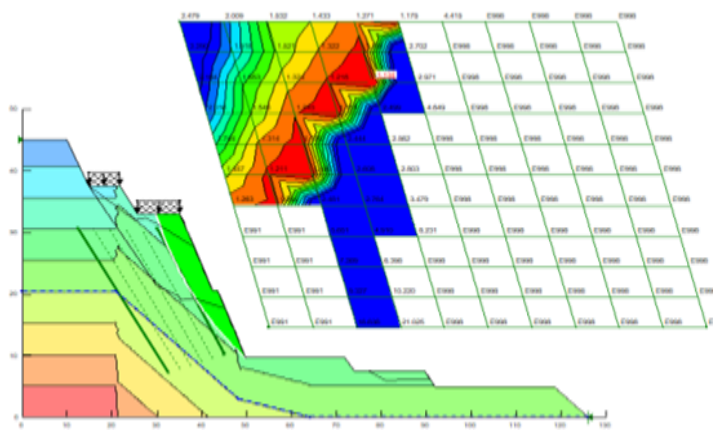

Gambar 17 Pola Kelongsoran Drained Kondisi Awal Metode Grid and Radius

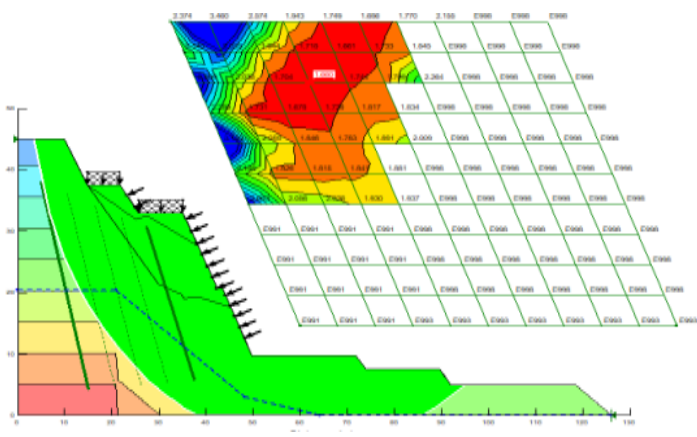

Gambar 19 Pola Kelongsoran Drained Keadaan Dinamis Metode Grid and Radius 


\section{Analisis perbedaan gaya ground anchor dan soil nailing pada keadaan statis dan dinamis}

Analisis dengan menggunakan program Plaxis $2 D$ akan menghasilkan gaya tarik yang bekerja pada ground anchor dan soil nailing. Gaya tarik yang dihasilkan untuk kondisi undrained akan ditampilkan melalui grafik pada gambar 20 dan 21 .

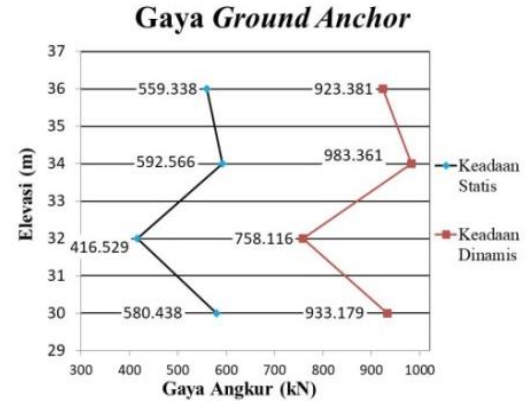

Gambar 20 Gaya Tarik Yang Bekerja Pada Ground Anchor Kondisi Undrained

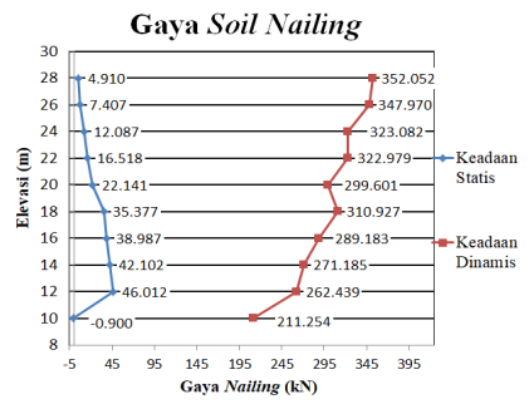

Gambar 21 Gaya Tarik Yang Bekerja Pada Soil Nailing Untuk Kondisi Undrained

Sedangkan, untuk gaya tarik yang bekerja pada ground anchor dan soil nailing untuk kondisi drained akan ditampilkan pada gambar 22 dan 23.

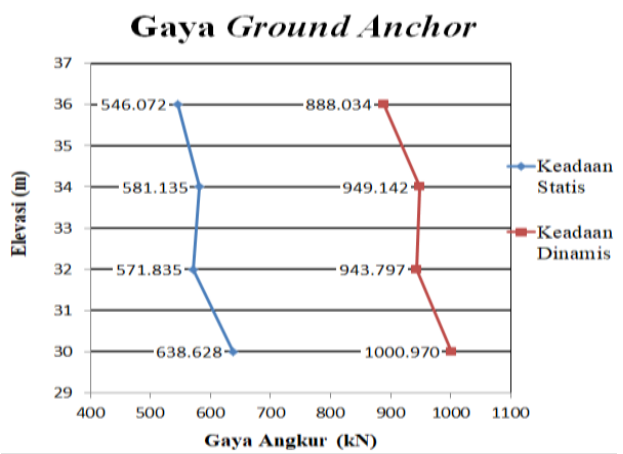

Gambar 22 Gaya Tarik Yang Bekerja Pada Ground Anchor Untuk Kondisi Drained

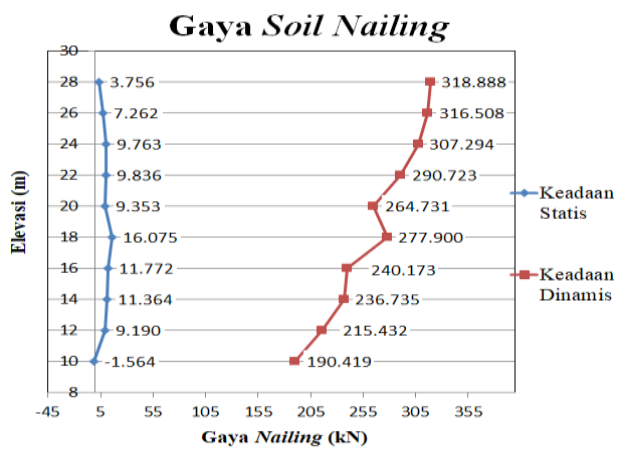

Gambar 23 Gaya Tarik Yang Bekerja Pada Soil Nailing Untuk Kondisi Drained

\section{Analisis perbandingan perkuatan lereng kondisi undrained dan drianed pada plaxis $2 D$ dan geoslope.}

Dalam melakukan analisis perkuatan lereng dengan mengkondisikan undrained dan drained akan menghasilkan nilai keamanan yang berbeda untuk kondisi undrained dan drained pada program Plaxis $2 D$ yang terdapat pada gambar 24 dan 25 .

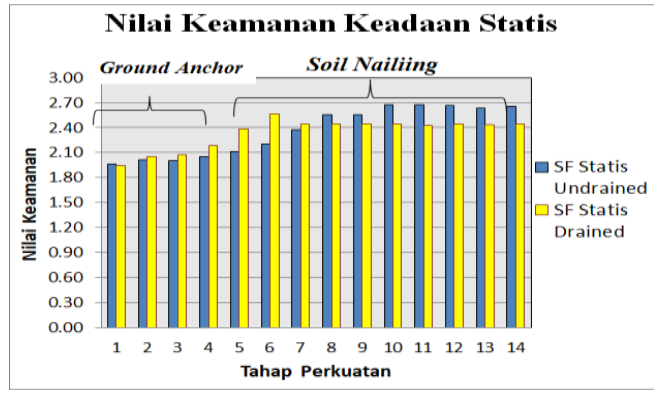

Gambar 24 Perbedaan Nilai Keamanan Kondisi Undrained dan Drained Pada Keadaan Statis

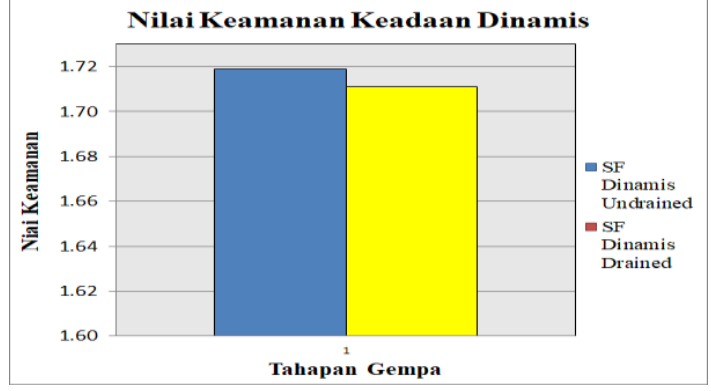

Gambar 25 Perbedaan Nilai Keamanan Kondisi Undrained dan Drained Pada Keadaan Dinamis 
Selain dari program Plaxis $2 D$ perbedaan nilai keamanan dapat dilihat dari program Geoslope pada metode grid and radius dapat dilihat pada gambar 26.

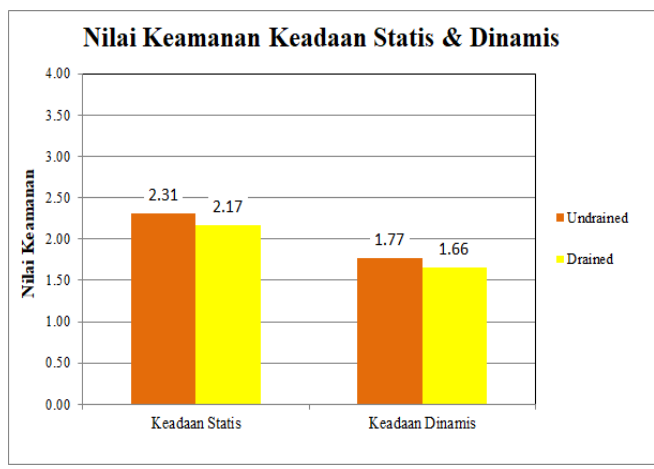

Gambar 26 Perbedaan Nilai Keamanan Untuk Kondisi Undrained dan Drained Metode Grid \& Radius

Berdasarkan gambar diatas, baik dari program Plaxis 2D dan Geoslope dengan metode grid and radius menghasilkan nilai keamanan dimana kondisi undrained yang lebih besar dibandingkan dengan kondisi drained. Hal ini menyatakan bahwa lereng dalam kondisi kritis saat kondisi drained.

\section{Analisis perbandingan program plaxis $2 D$ dan geoslope saat perkuatan lereng}

Perbandingan yang dihasilkan dapat dilihat dari nilai keamanan dan pola keruntuhan yang terjadi pada kedua program. Pada tabel 3 akan tertera nilai keamanan dari kedua program.

Tabel 3 Perbandingan Nilai Keamanan Pada Plaxis 2D dan Metode Grid \& Radius Kondisi Undrained dan Drained

\begin{tabular}{|c|c|c|c|c|c|}
\hline \multirow{2}{*}{ Metode } & \multicolumn{2}{|c|}{ Faktor Keamanan } & \multirow{2}{*}{ Metode } & \multicolumn{2}{|c|}{ Faktor Keamanan } \\
\hline & Statis & Dinamis & & Statis & Dinamis \\
\hline Plaxis Undrained & 2.65 & 1.72 & Plaxis Drained & 2.44 & 1.71 \\
\hline Grid \& Radius & 2.31 & 1.76 & Grid \& Radius & 2.17 & 1.66 \\
\hline
\end{tabular}

Berdasarkan tabel 3, nilai keamanan yang dihasilkan tidak berbeda jauh. Namun, hal ini tidak dapat dijadikan acuan dan harus diliat dari pola keruntuhan yang terjadi. Untuk kondisi undrained pada keadaan statis dapat dilihat pada gambar 27 dan keadaan dinamis pada gambar 28.

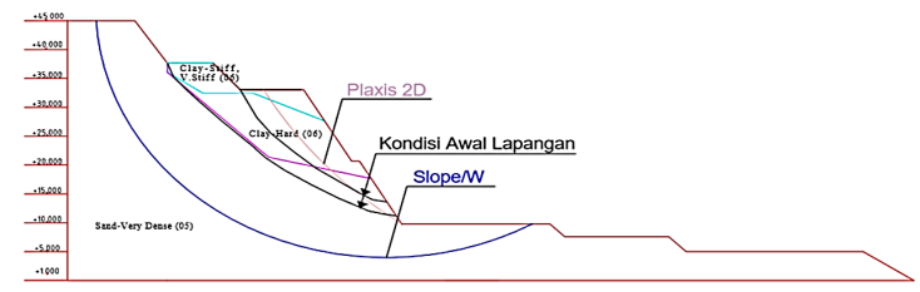

Gambar 27 Perbandingan Pola Keruntuhan Undrained Statis Plaxis 2D dan Grid and Radius

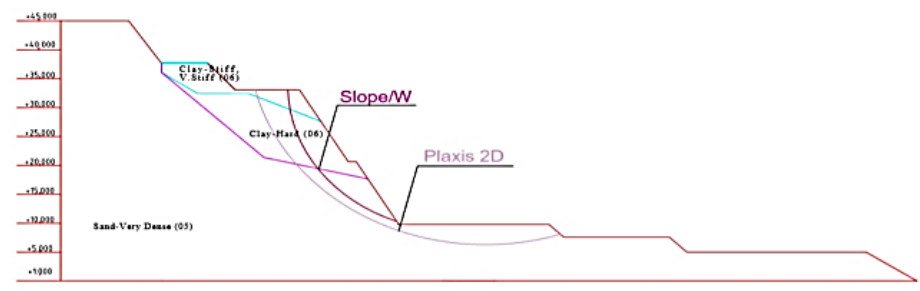

Gambar 28 Perbandingan Pola Keruntuhan Undrained Dinamis Plaxis 2D dan Grid and Radius 
Sedangkan, pola keruntuhan pada kondisi drained statis terdapat pada gambar 29 dan drained dinamis pada gambar 30 .

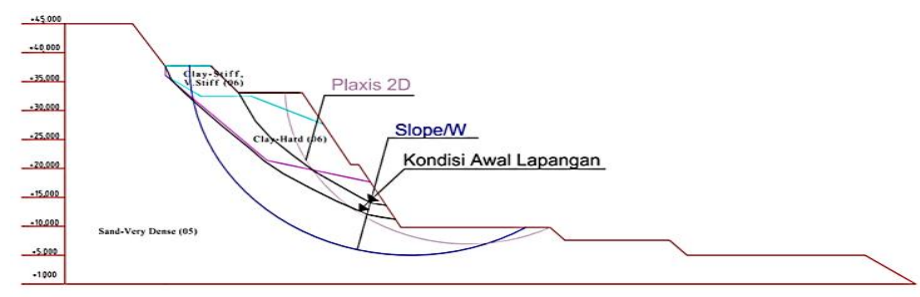

Gambar 29 Perbandingan Pola Keruntuhan Drained Statis Plaxis 2D dan Grid and Radius

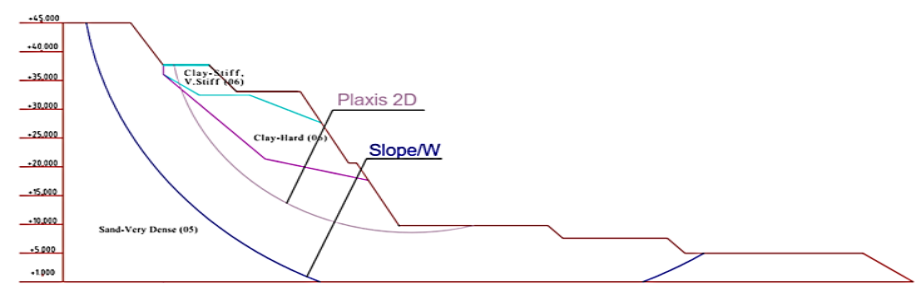

Gambar 30 Perbandingan Pola Keruntuhan Drained Dinamis Plaxis 2D dan Grid and Radius

Berdasarkan pola keruntuhan yang terbentuk, hasil dari metode Grid \& Radius cukup berbeda jauh dengan prediksi pola keruntuhan pada keadaan nyata dan hasil dari Plaxis 2D. Hal ini disebabkan karena pada metode ini kita mencari nilai keamanan dengan mengasumsikan titik pusat kelongsoran. Selain itu, pada metode ini pola yang terbentuk dipaksakan untuk menjadi pola circular dan dalam melakukan analisis dengan menggunakan program Geoslope tidak dimodelkan perkuatan yang digunakan seperti pada Plaxis $2 D$.

\section{KESIMPULAN}

Berdasarkan hasil back analysis yang dilakukan dengan menggunakan program Plaxis $2 D$ dan Geoslope pada kondisi undrained dan drained, dapat disimpulkan sebagai berikut :

1. Pola gerakan massa yang terjadi berada diantara tipe pergerakan single rotational slide dan multiple rotational slide.

2. Perkuatan yang digunakan adalah permanent ground anchor dan soil nailing dengan jarak horizontal dan vertikal 2 m dengan sudut kemiringan $30^{\circ}$.

3. Setelah dilakukan back analysis nilai SF yang diperoleh dengan menggunakan Plaxis $2 D$ dan program Slope/W dapat dilihat pada tabel 4 .

Tabel 4 Nilai Keamanan

\begin{tabular}{|c|c|c|c|c|}
\hline \multirow{2}{*}{ Metode Perhitungan } & \multicolumn{4}{|c|}{ Nilai Keamanan } \\
\cline { 2 - 5 } & \multicolumn{2}{|c|}{ Undrained } & \multicolumn{2}{c|}{ Drained } \\
\cline { 2 - 5 } & Statis & Dinamis & Statis & Dinamis \\
\hline FEM & 2.65 & 1.72 & 2.44 & 1.71 \\
\hline Grid \& Radius & 2.31 & 1.76 & 2.17 & 1.66 \\
\hline
\end{tabular}

4. Analisis stabiliats lereng dengan menggunakan program Geoslope dan Plaxis 2D menghasilkan nilai keamanan yang lebih kecil untuk kondisi drained dibandingkan kondisi undrained.

5. Perbedaan hasil dari program Plaxis $2 D$ dengan metode grid and radius disebabkan karena konsep dasar perhitungan pada grid and radius adalah dengan menentukan titik-titik pusat dan radius lingkaran secara trial and error. 


\section{DAFTAR PUSTAKA}

Bowles, J.E. (1991). Sifat-sifat Fisis dan Geoteknis Tanah (Mekanika Tanah) Edisi kedua. Jakarta : Erlangga. British Standard Institution. (1989). “Code of Practice For Ground Anchorages”. Publikasi : BS 8081 : 1989.

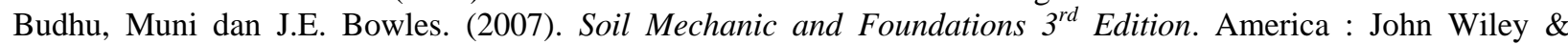
Sons,Inc.

Byrne, R.J. (1996). "Manual for Design and Costruction Monitoring of Soil Nail Wall”. Publikasi : FHWA-SA-96069R. Washington, D.C. Federal Highway Administration.

Hunt, Roy E. (2005). Geotechnical Engineering Investigation Handbook (Second Edition). New York : Taylor \& Francis Group.

Plaxis 2D Tutorial Manual. The Netherlands. (2016).

Plaxis Material Models Manual. The Netherlands. (2016).

SNI 8460:2017. Persyaratan Perancangan Geoteknik.

Terzaghi, Karl and Peck, B. Ralph.(1967). Soil Mechanics in Engineering Practice, Second Edition. New York : John Wiley \& Sons.

Wesley, Laurence D.(2012). Mekanika Tanah Untuk Tanah Endapan \& Residu. Yogyakarta : Andi 